\title{
AEG JA ASPEKT
}

\author{
Miina Norvik ja Piret Piiroja \\ Tartu Ülikool
}

\begin{abstract}
Kokkuvõte. Artikli eesmärgiks on anda teoreetiline ülevaade aja- ja aspektikategooriast ning siduda eesti aja- ja aspektikäsitlusi maailma keeleteaduse vastavate uurimissuundadega. Ajakategooria puhul tuuakse välja selle deiktiline olemus ehk vajadus pidepunkti järele, ning näidatakse, kuidas lähtepunktist tulenevalt eristuvad absoluutne, relatiivne ja absoluut-relatiivne aeg. Seejärel tutvustatakse Hans Reichenbachi (1947) jooniste alusel üht võimalust, kuidas keelelist aega esitada graafiliselt: näidatakse, kuidas kujutatakse oleviku, mineviku ja tuleviku aega, võttes arvesse kõnehetke, sündmushetke ja vaatlushetke. Aspekti juures seletatakse aspekti mittedeiktilisust, kuid samas rõhutatakse selle seotust ajaga. Artiklis antakse ülevaade grammatilise aspekti tüüpilisest vastandusest, milleks on imperfektiivsus versus perfektiivsus, tutvustatakse Zeno Vendleri (1967) situatsioonitüüpe ning tuuakse esile, et aspektist saab rääkida ka lausest suuremate üksuste puhul. Põgusalt on käsitletud ka aja ja aspekti teiseseid tähendusi.
\end{abstract}

Märksõnad: aeg, ajavormid, aja graafiline kujutamine, aspekt, situatsioonitüübid, Aktionsart

\section{Sissejuhatus}

Nii aja- kui ka aspektikategooria on keeltes enamasti verbi grammatilised kategooriad (Bybee jt 1994: 3). Need on lähedalt seotud kõneviisikategooriaga. Sellele osutab muuhulgas see, et tavaks on rääkida TAM-kategooriatest ehk aja-, aspekti- ja kõneviisikategooriatest (inglise keeles vastavalt tense, aspect, mood categories). Põhjusel, et eriti just aeg ja aspekt on omavahel tihedalt põimunud, käsitletakse siinses artiklis ennekõike aja ja aspektiga seonduvat.

Östen Dahli (1985: 10) järgi on iga kategooriaga seoses esitatavad esmased ja teisesed tähendused. Selliselt on ajakategooria puhul kõige olulisem aja väljendamine, aspektikategooria 
puhul aga aspekti väljendamine. Teiseseks tähenduseks nii ajakui ka aspektikategooria korral on enamasti mõne muu TAMkategooria tähendus (Dahl 1985: 23).

Dahl (1985: 24) esitab järgmised ajakategooriale tüüpilised jooned:

- aeg avaldub verbi morfoloogilises või perifrastilises vormis,

- ajavorm väljendab sündmushetke ja kõnehetke seost,

- aeg on alati väljendatud: iga ajavormi puhul on võimalik öelda, kas on tegemist oleviku, mineviku või tulevikuga.

Sarnaselt ajakategooriaga on ka aspektikategooria tihedalt seotud ajaga, kuid erineval viisil. Bernard Comrie (1976: 5) sõnul ei väljenda aspekt erinevalt ajakategooriast kõne- ja sündmushetke suhet, vaid sündmuse sisemist ajalist struktuuri.

Järgnevalt võetakse aeg ja aspekt lähema vaatluse alla. Osa 2 keskendub ajale, osa 3 aspektile, osa 4 käsitleb tüüpiliselt aega või aspekti väljendavate vahendite teiseseid tähendusi ning osa 5 aja ja aspekti uurimist eesti keeles.

\section{Aeg}

\subsection{Ajakategooriast üldiselt}

Enamasti on keeltes grammatilised vahendid sündmuse toimumisaja väljendamiseks, st ennekõike on aeg ,grammatiline kategooria, mis lokaliseerib verbiga väljendatava tegevuse ja seega kogu lausega väljendatava sündmuse mingi tingliku ajalise lähtepunkti suhtes: kõnehetke või teise sündmuse toimumisaja suhtes" (EKG I: 74). Näiteks lauses (1) on -si- lihtmineviku tunnus, mis viitab sellele, et sündmus leidis aset enne kõnehetke. Niisugustes keeltes, kus aeg on grammatiline kategooria, on mingid reeglid, mis teevad teatud ajavormi valiku kohustuslikuks, nt lauses (1) ei ole võimalik asendada lihtmineviku vormi olevikuvormiga - see muudaks lause anomaalseks (Dahl ja Velupillai 2011c).

(1) Ma ostsin endale eelmisel aastal auto. 
Samas leidub ka keeli, milles grammatilised vahendid aja väljendamiseks puuduvad. Comrie (1993: 51) toob näiteks birma ja dirbali keele, kus on kasutusel lauselõpulised partiklid, mis märgivad eristust realis (praegu aset leidev või varem aset leidnud sündmus) : irrealis (võimalik, kujuteldav sündmus). Lisaks saab aega sellistes keeltes väljendada leksikaalselt, st ajamääruste abil. Katarzyna M. Jaszczolti (2009: 82) sõnul tõestab grammatilise ajakategooriata keelte olemasolu, et aja väljendamine grammatiliste vahenditega ei ole keeles hädavajalik. Samuti nendib Jaszczolt, et ka keeled, milles aega grammatiliselt väljendatakse, vajavad sellele lisaks suurel hulgal leksikaalseid vahendeid. Ka eesti keeles kasutatakse grammatiliste ajavormide kõrval hulgaliselt määrusi (nt möödunud nädalal, praegu, homme hommikul).

Keeltes, kus aeg on grammatiline kategooria, on aeg osa deiktilisest raamistikust: see grammatiseerib suhte sündmuse toimumisaja ja deiktilise konteksti ajalise nullpunkti (st kõnehetke) vahel (Lyons 1977: 678). Vastavalt sellele, kas lähtepunktiks on kõnehetk või teise sündmuse toimumisaeg, on võimalik eristada absoluutset ja relatiivset aega. Absoluutse aja korral on deiktiliseks tsentriks kõnehetk, relatiivse aja puhul on aga üks sündmus seostatud mingi teise sündmuse toimumisajaga. Selliselt on absoluutne aeg otseselt seotud kõnehetkega, relatiivse aja puhul vormistub kõnehetk pidepunktina vaid kaudselt. (Comrie 1993: 36, 56) Morfoloogilistest ajavormidest väljendavad eesti keeles ennekõike absoluutset aega finiitse verbivormi lihtajad, nt lause (2) tegevust vaadeldakse kõnehetke seisukohalt. Infiniitsed verbivormid väljendavad relatiivset aega, nt lause (3) puhul seostatakse omavahel kaks sündmust (jalutamine ja kohtamine). Verbi kohtas tõttu paigutub sündmus minevikku; kuna jalutamine toimus samaaegselt kohtamisega, on tegemist mineviku olevikuga. (EKG I: 74-75)

(2) Naine jalutas koeraga.

(3) Koeraga jalutades kohtas naine oma venda.

Võimalik on siiski ka absoluutse ning relatiivse aja põimumine. Näiteks eesti keele liitaegade - perfekti ja pluskvam- 
perfekti - korral saab rääkida absoluut-relatiivsest ajast: tegevus suhestatakse kõnehetkega, lisaks on oluline tegevuse eelnevus, samuti vaatlushetk (vt ka osa 2.2). (Metslang 1994: 16, Comrie 1993: 65) Täpsemini on vaatlushetk kõnehetkele langev, eelnev või järgnev hetk ajas, mille seisukohalt sündmusi vaadeldakse. Morfoloogiliste vormide kõrval väljendavad eesti keeles ajasuhteid mõned perifrastilised vormid, ajamäärused ja lauselaiendid. Üldjuhul on ajaorientatsioon absoluutne iseseisvas lauses, relatiivne aga kõrvallauses ja sekundaartarindis. (EKG I: 75)

Verbi ajavormi tähendus sõltub sündmuse ja kõnehetke seosest. Tegemist võib olla samaaegsuse, eelnevuse või järgnevusega, millest tulenevalt eristuvad oleviku-, mineviku- ja tulevikuaeg. Lisaks on oluline vaatlushetk, mis vastava seose loob. (EKG I: 74-75) Taolist ajavormide käsitlust, mis võtab arvesse sündmus-, kõne- ja vaatlushetke, tuntakse Reichenbachi süsteemina. Algselt pärineb idee Otto Jespersenilt, kelle lähenemist Hans Reichenbach edasi arendas, tutvustades seda teoses „Elements of symbolic logic" (1947). Dahli (1985: 30) järgi töötab vastav süsteem kõige paremini just ajaliste suhete väljendamisel, aspektuaalsete nüansside kirjeldamiseks sobib see vähem.

\subsection{Ajavormid ja nende graafiline kujutamine}

Siinses osas tutvustatakse lähemalt ajakategooria liikmeid: oleviku, mineviku ja tuleviku aega. Muuhulgas on neid kujutatud graafiliselt ajateljel, näidates sündmushetke, kõnehetke ja vaatlushetke seost. Joonis 1 pärineb Comrielt (1993), joonised 2-6 Reichenbachilt (1947). Nagu järgnevate graafikute korral nii ka üldiselt on tavapärane esitada aega joonena. Näiteks Comrie (1993: 2) nendib, et ajast võib mõelda kui joonest, millel olevikulist ajahetke tähistab 0 , kõik, mis on toimunud minevikus, paigutub joonisel deiktilisest nullpunktist vasakule, ja kõik, mis leiab aset tulevikus - paremale (vt joonist 1). Comrie ütleb, et jätab oma joonisel lahtiseks selle, kas olevikuline ajahetk on pidevas liikumises (moving ego 'liikuv ego') või möödub aeg paigalpüsivast olevikulisest ajahetkest (moving time 
'liikuv aeg') (liikuva ego ja liikuva aja kohta vt nt McTaggart (1908), Traugott (1978), Evans (2004: 60-61)).

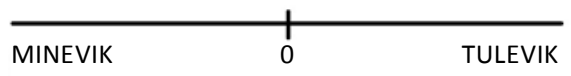

Joonis 1. Aja graafiline kujutamine (Comrie 1993: 2)

Oleviku all mõistetakse tavaliselt kõnehetkega kokkulangevat hetke: tüüpjuhul tähendab see sündmus-, kõne- ja vaatlushetke samaaegsust (vt joonist 2). Ometi ei pea olevikuvormiga väljendatud sündmus tingimata momentaanne olema, see võib ka kauem kesta (nagu lauses 4). Samuti võib olevikuvormiga väljendatud sündmus olla harjumuspärane (vt lauset 5). (Comrie 1993: 37-38) Eesti keeles märgitakse ka tulevikku üldiselt olevikuvormi abil. Tuleviku puhul on vaatlus- ja sündmushetk kõnehetkest hilisemad (vt joonist 3). Helle Metslangi (1994: 148) järgi on eesti keeles perfektiivse sündmuse korral tulevikutõlgendus tingitud aktuaalsena kasutatud olevikuvormist (6), imperfektiivse sündmuse puhul aitab tulevikulisust näidata ajamäärus või muu kontekstivahend (7).

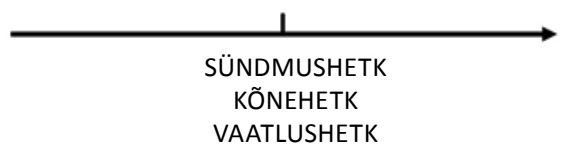

Joonis 2. Oleviku graafiline kujutamine (Reichenbach 1947: 290)

(4) Vanaisa magab.

(5) Liis käib igal hommikul jooksmas. 
58 Miina Norvik ja Piret Piiroja

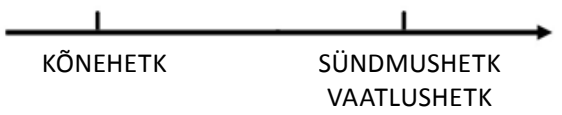

Joonis 3. Tuleviku graafiline kujutamine (Reichenbach 1947: 290)

(6) Isa ehitab maja valmis.

(7) Järgmisel aastal suvitan ma Hispaanias.

Mineviku korral on tegemist kõnehetkele eelnenud ajaga (Comrie 1993: 41), mille puhul sündmus- ja vaatlushetk on varasemad (vt joonist 4 ning lauset 9). Keeltes on mineviku all võimalikud edasised liigitused, nt võib olla välja toodav perfekt, pluskvamperfekt. Perfekt väljendab situatsiooni, milles vaatlushetk langeb kokku kõnehetkega ning sündmushetk eelneb neile (vt joonist 5 ja lauset 10), pluskvamperfekt aga olukorda, kus nii sündmus-, vaatlus- kui ka kõnehetk asuvad ajatelje eri punktides (joonis 6, lause 11). Perfekti seosest aspektiga vt lähemalt osast 4.

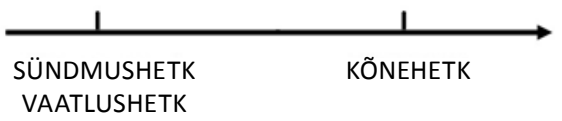

Joonis 4. Lihtmineviku graafiline kujutamine (Reichenbach 1947: 290)

(9) Eelmisel aastal töötas Anneli ajakirjanikuna.

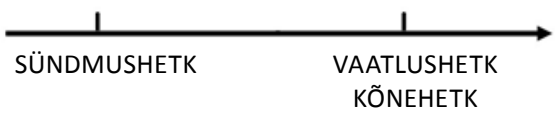

Joonis 5. Perfekti graafiline kujutamine (Reichenbach 1947: 290)

(10) Ta on oma elus palju reisinud. 


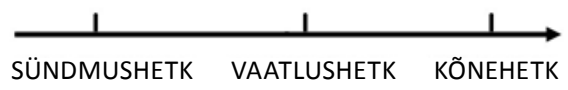

Joonis 6. Pluskvamperfekti graafiline kujutamine (Reichenbach 1947: 290)

(11) Selleks ajaks oli poeg juba kodust ära läinud.

Lisaks võib keeles esineda mitu minevikuajavormi selleks, et eristada sündmuse täpsemat toimumisaega (nt üks minevikumarker tähistab sündmusi, mis toimusid umbes nädal tagasi, teine sündmusi, mis toimusid umbes kuu aega tagasi jne). Näiteks Peruus kõneldavas jagua keeles on Dahli ja Velupillai (2011a) andmetel kokku viis erinevat minevikumarkerit eri aegadel toimunud sündmuste tähistamiseks (näidetes 8a-b on esitatud neist kaks):

(8) a. sa- dii- chi- myaa

3SG-surema- PST1-PERF

'Ta on surnud (nädal kuni kuu aega tagasi)'

b. $s a-$ dii- $\quad$ tí- myaa

3SG-surema-PST2-PERF

'Ta on surnud (paar kuud kuni aasta tagasi)'

Lause (8a) sisaldab minevikumarkerit -chi, mis tähistab ajavahemikku üks nädal kuni kuu aega tagasi, lauses (8b) on see aga asendatud minevikumarkeriga $-t i$, mis viitab ajavahemikule üks kuni kaks kuud kuni aasta tagasi. (Dahl ja Velupillai 2011a)

Tulevik on veel olemata aeg, mis paigutub kõnehetkele järgnevasse aega (vt joonist 3). Maailma keeltes leidub tuleviku väljendamiseks nii morfoloogilisi kui ka perifrastilisi vahendeid, neist esimeste olemasolu keeles viitab üldiselt suuremale futuurumi grammatiseerumise astmele (Bybee jt 1994). Eesti keele naaberkeeltest on morfoloogiline tulevik näiteks läti keeles. Eesti keeles morfoloogilist tulevikuvormi aga ei esine ning 
tavapärane on tarvitada tuleviku väljendamiseks olevikuvormi, ometi leidub ka mõni vähem grammatiseerunud, ebaregulaarne tulevikutarind, näiteks saama $+m a$-infinitiiv, hakkama $+m a-$ infinitiiv (Metslang 1994: 99). Metslang (2006: 719) tõdeb, et kui saama-konstruktsioon on viimasel ajal oma kasutusala pigem kokku tõmmanud (esineb enamasti ühendina saab olema), siis hakkama-tarindi puhul võib täheldada selle levimist (nt leiduvad sellised ühendid nagu hakkab arutama/tegelema/uurima). Tulevikukategooriat ongi sageli peetud ebastabiilseks kategooriaks, mis on pidevas kujunemises/muutumises (Palmer 1986: 156).

Tuleviku käsitlemist ajakategooria liikmena on tegelikult ka kahtluse alla seatud. John Lyons (1977: 816), kes käsitleb olevikku ja minevikku ennekõike ajalise mõistena, tõdeb, et tulevik on üksnes harva ajaline mõiste: sageli on see seotud soovidele, järeldustele, oletustele jt modaalsetele nüanssidele viitamisega (vt ka osa 4). Seetõttu on tulevikku vahel peetud hoopis episteemilise modaalsuse alla kuuluvaks (Comrie 1993: 43). Dahli (2000: 313) järgi ongi põhiprobleem olnud selles, kuidas tulevikuvahendid ajaliste, modaalsete ja ka aspektuaalsete elementide poolest jagunevad ja millise kategooria all neid käsitleda.

Eesti keeles võib episteemilise modaalsuse ja tuleviku tähenduste segunemist näha näiteks verbi saama puhul, mis võib viidata võimalikkusele ja tõenäosusele, kuid on kasutusel ka tuleviku aja väljendajana. Näiteks lauses (12) väljendab saama tuleviku aega, kuid samas on tajutavad ka episteemilised võimalikkuse ja tõenäosuse tähendused.

(12) Kõik saab olema nii, nagu meie tahame.

Verbi saama modaalsest ja tulevikulisest kasutusest grammatiseerumise kontekstis on põhjalikumalt kirjutanud Ilona Tragel ja Külli Habicht (2012). 


\section{Aspekt}

\subsection{Vaatepunkti aspekt}

Aspekt on ajaga tihedalt seotud, kuid erinevalt ajast ei ole aspekt deiktiline kategooria (Dahl 1985: 24-25). Comrie (1976: 3) märgib, et aspekt väljendab eelkõige sündmuse sisemist ajalist kulgu. Aspektist rääkides peetakse peamiselt silmas perfektiivse (piiritletud) ja imperfektiivse (piiritlemata) aspekti vastandust. Perfektiivse aspekti puhul vaadeldakse sündmust justkui väljastpoolt, ühtse tervikuna, ilma selle sisemist ajalist struktuuri täpsustamata (vt verbi jõudma lauses 13). Imperfektiivse aspekti korral aga vaadeldakse sündmust seestpoolt, paigutades kõneleja või kuulaja selle sündmuse keskele (vt verbi ootama lauses 13). (Comrie 1976: 3-4)

(13) Buss ootas parajasti ees, kui kesklinna jõudsime.

Perfektiivsuse ja imperfektiivsuse vastandust võib nimetada ka vaatepunkti aspektiks, kuna niisugune aspekt ei väljenda situatsiooni sisemisi omadusi, vaid ainult kõneleja vaatepunkti situatsioonile (Dahl 1999: 30). Kõneleja võib üht ja sama situatsiooni esitada nii perfektiivse kui ka imperfektiivsena. Sarnasest nimetusest hoolimata tuleb perfektiivset aspekti eristada perfekti ajavormidest (vt osa 2.2.). Perfektiivsuse ja perfekti aegade omavahelisi seoseid käsitletakse pikemalt artikli neljandas osas.

Mõnel juhul eristatakse imperfektiivset aspekti ja progressiivi, mille prototüüpne funktsioon on väljendada käimasolevaid sündmusi. Dahl on üks neist, kes leiab, et progressiivi ei saa lugeda imperfektiivse aspekti alla kuuluvaks nähtuseks, kuna nende vahel on mitmeid erinevusi. Näiteks ei saa progressiivi tavaliselt kasutada harjumuspärastele tegevustele viitamiseks, see võib esineda vaid dünaamiliste situatsioonide korral ja kombineerub ühtviisi hästi nii oleviku, mineviku kui ka tulevikuga. Erinevalt imperfektiivist ja perfektiivist väljendatakse progressiivi enamasti perifrastiliste vormide abil. (Dahl 1985: 69, 90-93)

Viimasel ajal on ka eesti keeles täheldatud progressiivi levikut (nt Metslang 1994, 2006). Sellise tõlgenduse võib saada 
olema + põhiverbi supiini inessiivist koosnev tarind. Tarindi lähtetähendus on lokatiivne, nagu progressiivkonstruktsioonidel üldiselt (vt nt Bybee jt 1994), kuid mõnikord kasutatakse seda ka elusa subjekti kestva tegevuse väljendamiseks, mis on progressiivtarindi prototüüpne funktsioon. Lauses (14), mis vastab ennekõike küsimusele Kus ta on?, on tarindit kasutatud lokatiivse tähenduse väljendamiseks, lauses (15) aga käimasolevale tegevusele viitamiseks. Lisaks nimetatud kasutustele võib progressiivivorm väljendada ka imminentsust ehk sündmuse (sageli ka vältimatut) toimumist kohe lähitulevikus (16), järkjärgulist muutust (17) ja teisi tähendusi. (Metslang 2006: 717-718)

(14) Ta on suusatamas.

(15) Rootsi valitsus on võtmas krooni tugevnemist väga tõsiselt.

(16) Pomm on plahvatamas.

(17) Kas raamatukogude roll on nõrgenemas või tugevnemas?

Ka eesti keele puhul peavad paika Dahli väited progressiivi ja imperfektiivse aspekti erinevuste kohta. Harjumuspärastele tegevustele viitamiseks võime küll kasutada supiini inessiivi vormi, kuid mitte koos verbiga olema, vaid verbiga käima (nt käib kooris laulmas, käib jooksmas). Tüüpiliselt ei ole võimalik kasutada progressiivtarindit staatiliste situatsioonide korral (koos verbidega nagu teadma, paiknema) ning ka eesti keele progressivtarind on perifrastiline.

Aspekt ei pruugi igas keeles grammatilise kategooriana esineda. Näiteks eesti keeles ei peeta aspekti grammatiliseks kategooriaks, kuna meil ei väljendata aspekti regulaarselt. Helena Sulkala (1996: 168-169) märgib, et nii eesti kui ka soome keeles võib aspektist rääkida eelkõige lause tasandil, kuna aspekt ei väljendu neis keeltes verbi grammatilise kategooriana, vaid on nähtav hoopis lauses esinevate substantiivide kaudu. Perfektiivse ja imperfektiivse aspekti eristamiseks kasutatakse eesti keeles nii grammatilisi kui ka leksikaalseid vahendeid. Grammatiliseks vahendiks on enamasti sihitise kääne, mis perfektiivse aspekti 
puhul on tavaliselt nominatiiv või genitiiv, imperfektiivse aspekti korral aga partitiiv. Leksikaalsetest vahenditest on levinud perfektiivsusmarkerite nagu ära, välja, läbi jne kasutamine. Samas võib aga aspekt ka määramatuks jääda. (EKG II: 25) Perfektiivse aspektiga on tegemist näiteks lauses (18), lauses (19) tuleb kõne alla nii imperfektiivsus kui ka perfektiivsus.

\section{(18) Ma pesen nõud ära. \\ (19) Isa tuleb.}

\subsection{Aktionsart}

Sageli peetakse aspekti all silmas muuhulgas tegevuslaadi ehk Aktionsarti. Dahl (1999: 30) selgitab, et terminiga Aktionsart viidatakse situatsioonide objektiivsetele sisemistele omadustele (võib öelda, et Aktionsart klassifitseerib situatsioone). Näiteks verbiga surema tähistatud situatsiooni võib tavaliselt pidada punktuaalseks, verbiga jooksma tähistatud situatsiooni aga kestvaks.

Situatsioonitüüpide liigitamisel võetakse enamasti aluseks Zeno Vendleri (1967) neljane jaotus, milles eristatakse seisundeid, tegevusi, sooritusi ja saavutusi (vt tabel 1). Jaotus põhineb kolmel tunnusel, milleks on staatilisus/dünaamilisus, duratiivsus/momentaansus ning teelisus/ateelisus.

Tabel 1. Situatsioonitüübid Vendleri (1967) järgi

\begin{tabular}{|l|l|l|l|}
\hline Sündmus & Staatilisus & Duratiivsus & Teelisus \\
\hline $\begin{array}{l}\text { Seisund } \\
\text { teadma, sarnanema }\end{array}$ & + & + & - \\
\hline $\begin{array}{l}\text { Tegevus } \\
\text { jooksma, kirjutama }\end{array}$ & - & + & - \\
\hline $\begin{array}{l}\text { Sooritus } \\
\text { kilomeetrit jooksma, } \\
\text { ringi joonistama }\end{array}$ & - & + & + \\
\hline $\begin{array}{l}\text { Saavutus } \\
\text { võitma, mõistma }\end{array}$ & - & - & + \\
\hline
\end{tabular}


Staatilised situatsioonid on sisemiselt homogeensed ja ajas suhteliselt muutumatud. Näiteks lauses (20) väljendatud teadmine on igal selle hetkel üsna ühesugune võrrelduna dünaamiliste situatsioonidega, mis on igal oma kestuse hetkel erinevad, koosnedes justkui paljudest väiksematest osadest. Nii näiteks koosneb jooksmine (nt lauses 21) jala tõstmisest ja maha panemisest, teise jala tõstmisest jne.

(20) Ma tean, et Maa on ümmargune.

Duratiivseid situatsioone iseloomustab ajaline kestus, momentaanseid situatsioone aga tajutakse tavaliselt hetkelistena. Teelistel situatsioonidel on olemas loogiline lõpp-punkt, ateelistel situatsioonidel see aga puudub. Näiteks on lauses (21) väljendatud tegevuse loomulikuks lõpp-punktiks mänguväljakule jõudmine, lauses (22) esitatud tegevusel niisugust lõpp-punkti ei ole.

(21) Laps jookseb mänguväljakule.

(22) Mees jalutab pargis.

EKG (II: 24) peab oluliseks ka tegevuse eristamist protsessist, mille juures on otsustavaks teguriks agentiivsus. Nimelt on tegevuse (nt tantsima) puhul üldiselt olemas ka situatsiooni suhtes aktiivne, seda kontrolliv osaline, protsessi (nt sadama) korral see aga puudub. Vendleri liigitust on kasutanud eesti keeleteadlastest näiteks Reili Argus (2007) eesti keele verbi ajamorfoloogia ja aspektilisuse omandamise uurimisel ning Piret Piiroja (2010) oma magistritöös verbi hakkama aspektuaalse kasutuse kirjeldamisel.

Aspekti võib vaadelda väga erinevatel tasanditel, alates sõnast ning lõpetades diskursusetasandiga. Nagu eelnevalt mainitud, on paljude verbide tähenduses olemas lõpetatusele või kestvusele viitav komponent. Fraasitasandil võib verbi sisemist aspekti muuta lisatav täis- või osasihitis, lause tasandil aga näiteks koha- või ajamäärus. Nii väljendab näites (23a) esitatud lause piiritlemata situatsiooni, näidetes (23b) ja (23c) piiritlevad situatsiooni vastavalt sihitis ja ajamäärus. 
(23) a. Mari laulis.

b. Mari laulis kolm laulu.

c. Mari laulis kolm tundi.

Kuid aspekti saab käsitleda ka lausest suurema üksuse omadusena. Van Hout jt (2005: 7), kirjeldades Hinrichsi (1981, 1986) töid, toovad näite, et sündmustest rääkides saame neid esitada üksteisele järgnevatena ja seetõttu piiritletuna, kuid võime ka kirjeldada situatsiooni, milles erinevad sündmused toimuvad korraga ja kujutavad endast justkui vaadet olukorrale selle seest, ühe lühikese hetke jooksul nähtuna, võrdle Hinrichsi töödest pärinevaid eesti keelde pandud näiteid (24a) ja (24b). Näites (24a) järgnevad sündmused üksteisele ja iga sündmus on piiritletud sellele eelneva ja järgneva sündmusega. Näites (24b) toimuvad sündmused üheaegselt ja meil puuduvad andmed nende algus- ja lõpp-punkti kohta, seega võib öelda, et tegemist on imperfektiivse situatsiooniga.

(24) a. Uks avanes. President tõusis püsti. Ta tervitas meid ja palus meil istet võtta.

b. Uks avanes. President istus oma kabinetis. Ta ei näinud meid. Ta rääkis telefoniga.

Eri autorid on erinevatel seisukohtadel selle osas, kas aspekti ja Aktionsarti peaks rangelt lahus hoidma või mitte. Sasse (2002: 207) nimetab esimesi mitmemõõtmelisteks ja teisi ühemõõtmelisteks aspektikäsitlusteks. Sasse (2006: 537) esitab mitmeid põhjendusi mitmemõõtmeliste lähenemiste kasuks, millest peamiseks on peenemate semantiliste eristuste võimaldamine kahe aspektiliigi kombineerimisel. Sasse (2006: 538) märgib ka, et tänapäevaste aspektikäsitluste hulgas on mitmemõõtmelised lähenemised ülekaalus. 


\section{Aja ja aspekti teisesed tähendused}

Nagu juba mainitud, on tavapäraselt ajakategooriasse või aspektikategooriasse kuuluvatel liikmetel eristatavad ka teisesed tähendused.

Ajasuhete vormistamiseks kinnistunud vahendid võivad olla kasutusel ka modaalsuse väljendamisel. Näiteks inglise keeles on minevikuaegadega võimalik edasi anda muuhulgas ebareaalsust (I wish I knew 'Ma soovin, et ma teaksin', kus knew on 'teadsin'). Metslangi (1994: 103) järgi on paljudes keeltes vahendatud teatelaadi funktsioonis tavalised mineviku liitajad, sh eesti keeles (vt lauset 25).

\section{(25) 30 aastat tagasi olid/olevat/olla koolid olnud paremad kui praegu.}

Aspekti väljendamine võib esiplaanile kerkida tulevikuga seoses. Näiteks inglise tulevikutarindi be going to kohta on Frank R. Palmer (1990: 160-161) väitnud, et tihtipeale ei väljenda see ühemõtteliselt tulevikku, vaid hoopis jätkuvust olevikust tulevikku, mis lubaks vastavat konstruktsiooni käsitleda pigem aspekti all. Eesti keeles seostuvad aspekt ja tuleviku väljendamine verbi hakkama puhul, mis võib sõltuvalt kontekstist viidata kas tegevuse algusele või selle toimumisele tulevikus. Metslang (1994: 167) nendib, et leidub näiteid, mille korral ei ole üheselt selge, kas hakkama viitab neis algusele või tuleviku ajale. Nagu osast 2.2 ilmnes, võib tulevikuga seoses tõusta esile muuhulgas modaalsus: näidati, et verb saama võib tulevikulises lauses kanda ka võimalikkuse ja tõenäosuse tähendust. Trageli ja Habichti (2012) sõnul võisid just võimalikkuse, tõenäosuse ja ka õnnestumise tähendused luua eeldused saama kasutamiseks tuleviku väljendamiseks.

Habicht jt (2010) kirjeldavad ka mõned sajandid tagasi eesti keeles leidunud saksa mõjutustega tulevikulist tahtmaverbi kasutust, mille üheks näiteks toovad nad lause (28). 
(28) Ma tahhan ommiko warra wõidu sõnu teile lausuda, mis ühhe kuulsa Allotagguse targa suust óppisin .. (vana kirjakeele korpus, Kreutzwald 1850)

Tuleviku ja episteemilse modaalsuse seotust võib näha ka inglise keeles, kus tuleviku abiverbi will algseks tähenduseks on olnud 'soovima, tahtma' (Bybee jt 1994: 254-256).

Võimalik on ka aja ja aspekti omavaheline põimumine, nii on see näiteks perfektivormide puhul. Nimelt on üldjuhul tegemist lõpetatud tegevusele viitava vormiga (aspekt), teisalt aga tuleb kõne alla minevik (aeg). (Dahl ja Velupillai 2011b) Andrej Malchukov (2009: 25) on koostanud hierarhia, mis kirjeldab perfektiivse aspekti sobivust erinevate ajavormidega. Selle kohaselt kombineerub perfektiivne aspekt kõige paremini just mineviku ajaga ning kõige halvemini olevikuga, tulevik jääb aga hierarhias nende kahe vahele. See on Malchukovi arvates ka põhjuseks, miks vene keeles on oleviku ajavormi ja perfektiivse aspekti kombinatsioon omandanud hoopis tuleviku tähenduse.

Selgub, et aja- ja aspektikategooria on ka etümoloogiliselt teineteisega seotud. Bernd Heine ja Tania Kuteva (2002: 231) toovad välja, et maailma keeltes kujuneb perfekti ajavorm tihti perfektiivse aspekti markerist, progressiivse aspekti marker aga on aluseks oleviku ajavormi tekkele. Nad oletavad, et aspekti markerite grammatiseerumine aja markeriteks võib olla maailma keeltes üsna levinud. Näiteks eesti verbi hakkama kohta on Metslang (1994: 167) leidnud, et selle tulevikuline kasutus on kujunenud välja just tegevuse algust tähistavast aspektilisest kasutusest.

\section{Aja ja aspekti uurimisest eesti keeles}

Ka eesti keele kohta on tehtud aja ja aspekti väljendamist puudutavaid uurimusi. Kõige enam on selle teemaga tegelenud Helle Metslang, kelle doktoriväitekiri (1994) käsitleb põhjalikult aja ja aspekti küsimusi eesti ja soome keeles. Samuti on ta kirjutanud näiteks eesti minevikuvormide kasutamisest (1997) ning 
vaadelnud ajavormistiku püsimist ja muutumist (2006). Muuhulgas aspektile on oma doktoriväitekirjas tähelepanu pööranud Raili Pool (2007). Pool uurib, kuidas kasutavad täis- ja osasihitist eesti keelt teise keelena õppivad inimesed ning milliseid vigu nad sealjuures teevad. Sihitise kasutamist eesti keeles on käsitlenud ka Birute Klaas (1988, 1999). Vähemtuntud aspektinähtustega nagu prospektiiv, retrospektiiv ja avertiiv, mis viitavad erinevatele sündmuse eel- või järelfaasidele, on tegelenud Mati Erelt (2009) ning Erelt ja Metslang (2009). Tegevuse algust või tulevikulisust väljendavaid minema-verbi sisaldavaid liitpredikaate (nagu nt Vesi läheb keema, Õpik läheb kasutusele/ kasutusse) on uurinud Kadri Muischnek ja Heete Sahkai (2010), kes keskenduvad oma artiklis eelkõige niisuguste liitpredikaatide produktiivsusele keeles. Võrdlevalt vene keelega on ajaja aspektivorme käsitlenud Pille Eslon ja Ants Pihlak (1993). Helena Sulkala (1996) on koondanud põhjalikku ülevaateartiklisse eesti ja soome keele aspekti käsitleva kirjanduse tähtsamad seisukohad. Võttes aluseks tähenduse, näitab ta, missuguste vahendite abil seda saab väljendada.

\section{Kokkuvõte}

Aeg ja aspekt on verbi grammatilised kategooriad, mis on omavahel tihedalt seotud ja väljendavad sarnaseid tähendusi. Ajakategooria esitab kirjeldatava sündmuse asetust ajateljel kõnehetke ja vaatlushetke suhtes, aspektikategooria aga annab edasi sündmuse sisemist ajalist struktuuri. Sündmus-, kõne- ja vaatlushetke omavahelised suhted on aluseks ka ajakategooria teoreetilistes käsitlustes. Aspekti käsitlemisel kasutatakse teoreetilise alusena sageli Vendleri situatsioonitüüpide jaotust, mis liigitab sündmusi nende staatilisuse/dünaamilisuse, duratiivsuse/momentaansuse ja teelisuse/ateelisuse põhjal. Grammatilise aspektina mõistetakse enamasti siiski vaid piiritletud ja piiritlemata situatsioonide eristust. Eesti keeles on olemas grammatiline ajakategooria ja seega on aja väljendamine lauses kohustuslik. Ajatähendusi väljendavad nii morfoloogilised kui 
ka perifrastilised verbivormid. Grammatilist aspektikategooriat seevastu eesti keeles ei ole ja kuigi on olemas mitmesugused vahendid aspektieristuste edasiandmiseks, esineb palju ka neutraalse aspektiga lauseid, mille puhul ei ole võimalik öelda, kas lause väljendab piiritletud või piiritlemata situatsiooni.

\section{Aadress:}

Miina Norvik, Piret Piiroja

Eesti ja üldkeeleteaduse instituut

Tartu Ülikool

Jakobi 2, 51014 Tartu

E-mail: Miina.Norvik@ut.ee, Piret.Piiroja@ut.ee

\section{Kirjandus}

Argus, Reili (2007) „Eesti keele verbi ajamorfoloogia ja aspektilisuse omandamisest". Emakeele Seltsi aastaraamat 52, 7-32.

Bybee, Joan, Revere Perkins, William Paglicua (1994) The evolution of grammar: tense, aspect, and modality in the languages of the world. Chicago and London: University of Chicago Press.

Comrie, Bernard (1976) Aspect: an introduction to the study of verbal aspect and related problems. (Cambridge Textbooks in Linguistics.) Cambridge: Cambridge University Press.

Comrie, Bernard (1993) Tense. (Cambridge Textbooks in Linguistics.) Cambridge: Cambridge University Press.

Dahl, Östen (1985) Tense and aspect systems. New York: Basil Blackwell.

Dahl, Östen (1999) "Aspect: basic principles". In Keith Brown, Jim Miller, eds. Concise encyclopedia of grammatical categories, 30-37. Oxford: Elsevier Science.

Dahl, Östen (2000) "The grammar of future time reference in European languages". In Östen Dahl, ed. Tense and aspect in the languages of Europe, 309-329. Berlin and New York: Mounton de Gruyter.

Dahl, Östen, Viveka Velupillai (2011a) "The past tense". Matthew S. Dryer, Martin Haspelmath, eds. The world atlas of language structures online. Munich: Max Planck Digital Library, chapter 66. <http://wals. info/chapter/66>. Vaadatud: 09.11.2011.

Dahl, Östen, Viveka Velupillai (2011b) "The perfect". Matthew S. Dryer, Martin Haspelmath, eds. The world atlas of language structures online. Munich: Max Planck Digital Library, chapter 68. < http://wals. info/chapter/68>. Vaadatud: 09.11.2011. 
Dahl, Östen, Viveka Velupillai (2011c) "Supplement: tense and aspect". In Matthew S. Dryer, Martin Haspelmath, eds. The world atlas of language structures online. Munich: Max Planck Digital Library, supplement 7. <http://wals.info/supplement/7>. Vaadatud: 09.11.2011.

EKG II = Erelt, Mati, Reet Kasik, Helle Metslang, Henno Rajandi, Kristiina Ross, Henn Saari, Kaja Tael ja Silvi Vare (1993) Eesti keele grammatika II. Süntaks. Lisa: kiri. Trükki toimetanud Mati Erelt (peatoimetajana), Tiiu Erelt, Henn Saari, Ülle Viks. Tallinn: Eesti Teaduste Akadeemia Keele ja Kirjanduse Instituut.

EKG I = Erelt, Mati, Reet Kasik, Helle Metslang, Henno Rajandi, Kristiina Ross, Henn Saari, Kaja Tael ja Silvi Vare (1995) Eesti keele grammatika I. Morfoloogia, sõnamoodustus. Trükki toimetanud Mati Erelt (peatoimetajana), Tiiu Erelt, Henn Saari, Ülle Viks. Tallinn: Eesti Teaduste Akadeemia Keele ja Kirjanduse Instituut.

Erelt, Mati (2009) „Prospektiiv ja retrospektiiv eesti keeles”. Emakeele Seltsi aastaraamat 54, 44-53.

Erelt, Mati, Helle Metslang (2009) "Some notes on proximative and avertive in Estonian". Linguistica Uralica, 45, 3, 178-191.

Eslon, Pille, Ants Pihlak (1993) Vid $i$ vremja. (Trudy po sopostavitel'notipologicheskomu issledovaniju raznosistemnyh jazykov.) Tallinn: Tallinnskij pedagogicheskij universitet.

Evans, Vyvyan (2004) The structure of time: language meaning and temporal cognition. Amsterdam and Philadelphia: John Benjamins.

Habicht, Külli, Pille Penjam, Ilona Tragel (2010) „Kas tahtma tahab abiverbiks?". Eesti ja soome-ugri keeleteaduse ajakiri 1, 2, 115-146.

Heine, Bernd, Tania Kuteva (2002) World lexicon of grammaticalization. Cambridge: Cambridge University Press.

Hinrichs, E. (1981) Temporale anaphora im Englischen. Unpublished MA thesis. University of Tübingen.

Hinrichs, E. (1986) A compositional semantics for aktionsarten and NP reference in English. $\mathrm{PhD}$ dissertation. Ohio State University, Columbus.

van Hout jt = van Hout, Angeliek, Henriëtte de Swart, Henk J. Verkuyl (2005) "Introducing perspectives on aspect". In Henk Verkuyl, Henriette de Swart, Angeliek van Hout, eds. Perspectives on aspect, 1-18. Dordrecht: Springer.

Jaszczolt, Katarzyna M. (2009) Representing time: an essay on temporality as modality. Oxford: Oxford University Press.

Klaas, Birute (1988) „Indirektne objekt eesti keeles”. Keel ja Kirjandus 1, 37-42.

Klaas, Birute (1999) "Dependence of the object case on the semantics of the verb in Estonian, Finnish, and Lithuanian”. In Mati Erelt, ed. Estonian: Typological Studies III, 47-83. (Tartu Ülikooli eesti keele õppetooli toimetised, 11.) Tartu: Tartu Ülikooli Kirjastus.

Lyons, John (1977) Semantics. Vol. 2. Cambridge: Cambridge University Press. 
Malchukov, Andrej (2009) "Incompatible categories: resolving the 'present perfect paradox"'. In Lotte Hogeweg, Helen de Hoop, Andrej Malchukov, eds. Cross-linguistic semantics of tense, aspect, and modality, 13-31. Amsterdam: John Benjamins Publishing Company.

McTaggart, J. (1908) “The unreality of time". Mind 17, 457-474.

Metslang, Helle (1994) Temporal relations in the predicate and the grammatical system of Estonian and Finnish. (Oulun yliopiston suomen ja saamen kielen laitoksen tutkimusraportteja, 39.) Oulu: Oulun yliopisto.

Metslang, Helle (1997) "On the use of the Estonian past tense forms through the last one hundred years". In Mati Erelt, ed. Estonian: typological studies II, 98-145. (Publications of the Department of Estonian of the University of Tartu, 2.) Tartu: Tartu Ülikooli Kirjastus.

Metslang, Helle (2006) „Predikaat ajastut kogemas”. Keel ja Kirjandus 9, 714-727.

Muischnek, Kadri, Heete Sahkai (2010) „Liitpredikaadid leksikoni-grammatika kontiinuumil: konstruktsioonide produktiivsusest verbiga minema moodustatud liitpredikaatide näitel”. Eesti ja soome-ugri keeleteaduse ajakiri 1, 2, 295-316.

Palmer, Frank Robert (1986) Mood and modality. Cambridge: Cambridge University Press.

Palmer, Frank Robert (1990) Modality and the English modals. London: Longman.

Piiroja, Piret (2010) Verb hakkama situatsiooni alguse väljendajana eesti keele ahelverbides. Magistritöö. Käsikiri Tartu ülikooli eesti ja üldkeeleteaduse instituudis.

Pool, Raili (2007) Eesti keele teise keelena omandamise seaduspärasusi täisja osasihitise näitel. (Dissertationes Philologiae Estonicae, 19.) Tartu: Tartu Ülikooli Kirjastus.

Reichenbach, Hans (1947) Elements of symbolic logic. New York: The Macmillan Company.

Sasse, Hans-Jürgen (2002) "Recent activity in the theory of aspect: accomplishments, achievements, or just non-progressive state?'. Linguistic Typology 6, 199-271.

Sasse, Hans-Jürgen (2006) “Aspect and actionsart”. In Keith Brown, ed. Encyclopedia of language \& linguistics, 535-538. Amsterdam: Elsevier.

Sulkala, Helena (1996) "Expression of aspectual meanings in Finnish and Estonian”. In Mati Erelt, ed. Estonian: typological studies I, 165-225. (Publications of the Department of Estonian of the University of Tartu, 4.) Tartu: Tartu Ülikooli Kirjastus.

Tragel, Ilona, Külli Habicht (2012) "Grammaticalization of the Estonian saama 'get'". (Alexandra N. Lenz, Gudrun Rawoens, eds. The art of getting: GET verbs in European languages from a synchronic and diachronic point of view. Special issue.) Linguistics 50, 6, 1371-1412.

Traugott, Elizabeth Closs (1978) "On the expression of spatio-temporal relations in language". In Joseph E. Greenberg, Charles A. Ferguson, 
Edith A. Moravcsik, eds. Universals of human language. Vol. 3: Word structure. Stanford, California: Stanford University Press.

Vendler, Zeno (1967) Linguistics in philosophy. Ithaca, NY: Cornell University Press.

\begin{abstract}
Miina Norvik and Piret Piiroja: Tense and aspect. The aim of this paper is to give a theoretical overview of the cateories of tense and aspect. An attempt is made to bring together Estonian treatments of tense and aspect with the similar theoretical approaches in the world. In relation to the cateory of tense its deictic nature is emphasized and it is shown how it is possible to distinguish absolute, relative and absolute-relative tense depending on the reference point. Based on the drawings by Hans Reichenbach (1947) a way to represent tense graphically is introduced: it is demonstrated how present, past and future tenses can be represented by using the notions of 'point of speech', 'point of the event', and 'point of reference'. In relation to the category of aspect the non-deictic nature of aspect is explained, emphasizing at the same time that regardless of that there still is a connection with the category of tense, only of different nature. The article gives an overview of the typical aspectual distinction of imperfective versus perfective and introduces Zeno Vendler's (1967) situation types. It also points out that aspect can be a property of discourse segments larger than the sentence. The secondary meanings of tense and aspect are discussed only briefly.
\end{abstract}

Keywords: time, tense, graphical representation of tenses, aspect, situation types, Aktionsart 